\title{
The Efficiency of Indonesian Islamic Rural Banks: A Stochastic Frontier Analysis
}

\author{
Dian Agustina \\ Universitas Gadjah Mada, Indonesia, dian.agustina123@mail.ugm.ac.id \\ Mahfud Sholihin \\ Universitas Gadjah Mada, Indonesia, mahfud@ugm.ac.id \\ Annisa Fithria
}

Universitas Ahmad Dahlan, Indonesia, annisa.fithria@act.uad.ac.id

Article History

Received: December 17, 2018 Revised: January 4, 2019 Accepted: January 5, 2019

\begin{abstract}
Banking plays an important role in economy acting as an intermediation institution and funding sources for business. When a bank is inefficient in the use of cost, there will be improperly used input, hindering the bank to realize its roles, functions, and objectives. Therefore, analysis of bank efficiency is strongly required. This study aims to measure and analyze the technical efficiency of Indonesian Islamic rural banks by using balanced panel data of Indonesian Islamic rural banksfromquartile I 2011 to quartile IV 2016. The sample includes 58 Islamic rural banks with total 1,392 observations. By using stochastic frontier analysis,the result shows that the average technical efficiency of Indonesianlslamic rural banksreached 86 percent and there are still 14 percent that can be optimized. Overall, the average efficiency of Indonesian Islamic rural banksincreases over the research period. In addition, this study also finds that big banks are more efficient than small banks.
\end{abstract}

Keywords: Islamic rural bank, technical efficiency, stochastic frontier analysis, panel data.

JEL Classification: G21

@ IJIEF 2019 published by UniversitasMuhammadiyah Yogyakarta, Indonesia All rights reserved

DOI:

https://doi.org//ijief.1212
Web:

http://journal.umy.ac.id/index.php/ijief/article/view/1212

Citation:

Agustina, D., Sholihin, M., \& Fithria, A. (2019). The Efficiency of Indonesian Islamic Rural Banks: A Stochastic Frontier Analysis. International Journal of Islamic Economics and Finance (IJIEF), 1(2), 229-248. DOI: https://doi.org//ijief.1212. 
Agustina, Sholihin, \& Fithria|The Efficiency of Indonesian Islamic Rural Banks: A Stochastic Frontier Analysis.

\section{Introduction}

Banking plays an important role in economy in Indonesia. Banking industries constitutes the main institution acting as an intermediation institution and funding sources for developing countries (Fase \& Abma, 2003). In Indonesia particularly, banking functions as a collecting and distributing institution for social funds that supports national development implementation to improve equitable development, economic development, and national stability, leading to the improvement of living standards in Indonesia (OJK, 2016).

As one of financial institution, bank has both short-term and long-term objectives that should be achieved. The short-term objective is to maximize profits; while the later one is to maximize the owners' welfare. One of the strategies to manifest the objectives is by enhancing operational efficiency (Rose \& Hudgins, 2013).

Bank's operational efficiency is correlated to company ability to achieve the highest possible level of output by a number of inputs and certain technology. Such efficiency is well-known as technical efficiency (Farrel, 1957). When a bank is inefficient in the use of cost, there will be improperly used input, hindering the bank to realize its roles, functions, and objectives. Therefore, analysis of bank efficiency is strongly required.

Bank efficiency can be measured by using the ratio approach and frontier approach. Ratio approach measures the level of banking efficiency by using the comparison between operational cost and operational income. It is an approach that is relatively easy in calculation. However, as the weakness, it excludes the bank output (Muazaroh, 2013).

Frontier approach functions to measure efficiency value with various measurement types and methods. According to Farrel (1957), there are three types of efficiency at company, i.e. technical efficiency, allocative efficiency, and economic efficiency. Operational efficiency is the ability to produce an optimum output by a certain input number. Allocation efficiency is the ability to select the optimum input number from a certain number of production factor cost. Finally, economic efficiency, also known as cost efficiency, is the sum of operational efficiency and allocation efficiency.

In terms of method, there are two methods measuring efficiency: parametric and non-parametric. Non-parametric method consists of data envelopment analysis (DEA) and free disposal hull (FDH); while the parametric method consists of stochastic frontier analysis (SFA), distributionfree analysis (DFA), and thick frontier analysis (TFA) (Berger \& Humphrey, 1997). DEA and FDH approaches do not depend on the functional form of the relationship between input and output (Holod \& Lewis, 2011). Non- 
Agustina, Sholihin, \& Fithria|The Efficiency of Indonesian Islamic Rural Banks: A Stochastic Frontier Analysis.

parametric (DEA and FDH) method possesses weakness, it assumes that there is no random error existing (Berger \& Humphrey, 1997). SFA approach stipulates functional form for the relationship between input and output. SFA approach shows an advantage that is the assumption of random error. Contrastively, DFA and TFA approaches come with no strong assumption of random error. Therefore, this research applied the parametric method that was SFA approach.

This research focuses on Islamic rural banks in Indonesia. It is a part of banking system that plays a role for national economy, providing financing for low-income people. Often, it competes with other financing institutions, obliging it to operate efficiently in order to face competition within industries. Unfortunately, information regarding its efficiency is still limited, as the previous research of banking efficiency more focused on big banks, not on Islamic banks (Tahir \& Haron, 2008; Hasan, Kamil, Mustafa, \& Baten, 2012; Bhattacharyya \& Pal, 2013; Parinduri \& Riyanto, 2014; Manlagnit, 2015; Zhang \& Kang, 2015).

Research of Islamic rural banks' efficiency was conducted by Hosen \& Muhari (2013) and Sadono (2017). However, both research is still limited, because the research done by Hosen \& Muhari (2013) only employed the data collected from June 2011-December 2012, and Sadono (2017) only analyzed Islamic rural banks in East Java, so that data generated could not represent the population of Islamic rural banks in Indonesia for a long period. In that, this research intends to broaden and complement literatures of small bank efficiency, or Islamic rural bank, as one of the considerations to make decision for policy makers. This research sets aim to measure and analyze the efficiency of Indonesian Islamic rural banks for the 2011-2016 periodby implementing the stochastic frontier analysis (SFA) approach.

This research finds that the average technical efficiency of Islamic rural banks in Indonesia 2011-2016 achieves 86 percent; while there is the other one by 14 percent that can be optimized. In overall, the average efficiency of Indonesian Islamic rural banks increases during the research period. Additionally, this study also finds that big banks are more efficient than small banks.

The next part of this article explains the literature review continued by research method and results. This article ends by conclusion and recommendation for future researchers. 
Agustina, Sholihin, \& Fithria|The Efficiency of Indonesian Islamic Rural Banks: A Stochastic Frontier Analysis.

\section{Literature Review}

\section{Islamic Rural Banks}

Islamic banking is everything related to Islamic banks and sharia business units including institution, business activities, and strategies and processes in carrying their business activities. In running their business activities, Islamic banks refer to sharia principles. According to the types, there are two Islamic banks, i.e. Sharia commercial banks and Islamic rural banks. The main characteristic of Islamic rural banks is carrying out its activities without any service provision in the payment traffic (Law Number 21 Year 2008).

The first Islamic rural banks in Indonesia was founded in 1991 in West Java that were PT BPR Dana Mardhatillah, PT BPR BerkahAmal Sejahtera, and PT BPR AmanahRabbaniyah. Until June 2018, the number of Islamic rural banks in Indonesia was 168 (OJK, 2018).

After having a trend of slowing economic growth in 2010-2015, Indonesia's economy in 2016 began to show improvement, as clarified by the economic growth rate by 5.02 percent. In line with the improvement, national banking industries, still in the same year, also improved by 10.4 percent; while it was only 8.6 percent in 2016(OJK, 2017). In the end of 2016, Indonesian Islamic banking consisting of Sharia commercial banks, Sharia business units, and Islamic rural banks experienced asset improvement, with funding provided by the third-party funds were 20.28 percent, 16.41 percent, and 20.84 percent each (yoy).

\section{Efficiency}

Efficiency is one of the performance indicators of an entity. There are two approaches to estimate efficiency value, i.e. ratio approach and frontier approach. Ratio approach is the comparison between operational cost and operational income (BOPO). Ratio approach is one of the approaches usually used to measure the bank efficiency. However, ratio approach (BOPO) contains a weakness of not considering the relationship between input and output, hence being unable to represent the true bank condition(Qurniawati, 2013).

In addition to the ratio approach, frontier approach calculates bank efficiency to produce a better value. Efficiency measurement is performed by focusing on both output and input(Hadad, et al., 2003). Frontier approach consists of various types and measurement. Stochastic frontier approach (SFA) is one of the parametric methods to measure efficiency value. It was 
Agustina, Sholihin, \& Fithria|The Efficiency of Indonesian Islamic Rural Banks: A Stochastic Frontier Analysis.

proposed byAigner, et al. (1977) andMeeusen \& Broeck (1977), confirming that error term consisted of two independent components: $\varepsilon_{i}=V_{i}-U_{i} \cdot V_{i}$ is the two-sided error term defining statistical noise, and $U_{i}$ is the one-sided error term describing technical inefficiency.

Farrel (1957)argues that technical efficiency is the ability of a company to achieve the highest possible level of output by a certain number of input and technology. It is measured by employing an index, broadly known as technical efficiency score. The index ranges from zero to one. When the technical efficiency score is closer to one, company is said to produce more efficiently. However, when it is closer to zero, company is said to produce more inefficiently. Meanwhile, technical analysis consists of estimation of the best frontier(Kumbhakar \& Lovell, 2000).

\section{Previous Studies}

Research of efficiency by using stochastic frontier analysis (SFA) had been conducted. Tahir,et al. (2008) investigated operational efficiency by SFA approach in 22 commercial banks consisting of nine domestic banks, and 13 foreign banks in Malaysia by using imbalanced panel data 2000-2006. The research used input variables of total deposits (deposits from customers and deposits from other banks) and total overheard expenses (salary expenses and other operating expenses) and output variable that was total earning asset (financing, security investment, and placement with other banks). The findings confirmed that technical efficiency of 22 commercial banks was 81 percent, and that domestic commercial banks in Malaysia were more efficient than foreign commercial banks by the difference of 15.7 percent. Furthermore, efficiency value continued to increase within the periods.

Aysan, Karakaya, \& Uyanik (2011)examined the efficiency and its relation to profitability in Turkish banking sector by employing panel stochastic frontier approach in the post crises period. In theirstudy, both cost and profit efficiency measures were estimated for the panel data consisting of 32 banks between 2002-2007. Their results suggested that there is cost efficiency gain and convergence in the efficiency levels of banks. In addition, foreign banks are less efficient and state banks are more efficient.

Hasan,et al. (2012) observed technical efficiency in six commercial banks in Malaysia by using data of 2005-2010. The research used input variables total deposits (deposits from customers and deposits from other banks) and total overheard expenses (salary expenses and other operating expenses) and time; while the output variables was total earning asset (financing, security 
Agustina, Sholihin, \& Fithria|The Efficiency of Indonesian Islamic Rural Banks: A Stochastic Frontier Analysis.

investment, and placement with other banks). The findings conveyed that technical efficiency of commercial banks in Malaysia was 94 percent.

Bhattacharyya \& Pal (2013) analyzed technical efficiency in 48 commercial banks in India by using data of 1989-2009. The research applied an approach of bank as an intermediating institution to determine both input and output. Input included deposits, labors (compensation for labors; such as salary, training, and bonus), and capital (the amount of expenditure for electricity, fuel, water, payment of indirect taxes, and depreciation). Output covered investment and loan. The findings defined that technical efficiency of commercial bank in Indonesia was 64 percent.

Hosen \& Muhari (2013) investigated operational efficiency in 59 Islamic rural banks by using data of June 2011-December 2012. The research employed price of labor and price of fund as inputs, total financing and placement with other banks as output, and equity over total assets and non-performing financing as variables of environmental factor. The findings described that operational efficiency of Islamic rural banks in June 2011-December 2012 was 81.41 percent.

Bokpin (2013) examined the effect of ownership structure and corporate governance on bank efficiency in the Ghanaian banking industry. The study applies both accounting data and efficiency measures fromthe period19992007via paneldata analysis. Efficiencyismeasuredbycomputing distances from the stochastic frontiers of estimated translog cost and profit functions. The results suggested that foreign banks are more cost-efficient than domestic banks, but not necessarily more profit-efficient.

Parinduri \& Riyanto (2014) observed cost efficiency in 144 commercial banks in Indonesia during December 2000-June 2005. Research input included price of labor (ratio of salary expenses and total assets), price of fund (ratio of interest expense and interest-bearing debt), and price of capital (ratio of non-labor expense and the number of fixed assets); while the output included total bank loan, government obligation ownership, security ownership, and other assets. The findings explained that the most efficient banks were regional banks by 66 percent; while the most inefficient banks were the state banks by 55 percent.

Zuhroh, et al. (2015) investigated cost efficiency in Islamic banks by implementing the stochastic frontier analysis and factors affecting inefficiency. Research sample consisted of three Islamic banks and 19 commercial banks admitted in Indonesia Stock Exchange by using quartile III 2004-quartile IV 2014 data. Variables used in the research were cost efficiency (technical efficiency and allocative efficiency), competition, firm's size, equity of output, liquidity, and institutional structure. Findings indicated 
Agustina, Sholihin, \& Fithria|The Efficiency of Indonesian Islamic Rural Banks: A Stochastic Frontier Analysis.

that cost efficiency of Islamic banks was lower than that of commercial banks; while its operational efficiency was higher than that of commercial banks. Cost efficiency of Islamic banks was 17 percent; while that of commercial banks was 29 percent. The research also found out that technical efficiency of Islamic banks was higher by 66 percent; while that of commercial banks was 46 percent.

Zhang \& Kang (2015)observed cost efficiency of government banks and jointstock banks in China by applying the stochastic frontier analysis. Data were analyzed by using panel date of banks in 2000-2011 in China. Research sample involved eight commercial banks in China. There were two inputs, i.e. average cost of loan fund and average cost of business investment. Besides, there were three outputs, i.e. outstanding loans, non-interest income, and investment by securities. Research findings proposed that banking in China had grown more efficient by 86 percent. However, banks with joint shares were proven to have lower efficiency than the government banks with a relatively small difference.

Manlagnit (2015) examined the impacts of Basel II on cost efficiency of 17 commercial banks in Philippines in 2001-2011. Approach implemented to assess cost efficiency was stochastic frontier analysis. Manlagnit used the intermediating approach to determine both input and output. Based on the approaches, as a monetary intermediary, bank employed labors, capital, deposits, and other loan funds to produce earning assets. Dependent variable in the research was InTC, the sum of operating and financial expenses. There were three outputs that were total loans, securities, and contingent accounts. There are three inputs that were wage rate (ratio of salary expense and total asset), physical price of capital (ratio of occupancy expense from fixed asset), and price of fund (ratio of interest expense on total fund). The research revealed that higher capital needs tended to fix efficiency and more authorized supervisor could influence bank efficiency. Other potential variables that could help explain bank efficiency was risks, asset quality, and specific variables of the bank. The research confirmed that cost efficiency of commercial banks in Philippines in 2000-2011 was 75 percent.

Khalib, et al. (2016) analyzed cost efficiency of banking in Malaysia. They used data collected from 16 Islamic banks and 27 conventional banks in 1994-2014. Analysis of efficiency was done by implementing the stochastic frontier analysis method. Dependent variable used in the research was InTC. Components of input hired were labor price, physical price of capital, labor price; while components of outputs consisted of the amount of loan and acquisition of other assets (securities, deposits with other banks). Their research findings confirmed that Islamic banking had a higher efficiency 
Agustina, Sholihin, \& Fithria|The Efficiency of Indonesian Islamic Rural Banks: A Stochastic Frontier Analysis.

value that was 99.7 percent; while conventional banking had an efficiency value of 96.9 percent. The value difference was not too distant, that was 2.8 percent.

Aiello \& Bonanno (2016) investigated 104 small mutual-cooperative banks' (BBC) cost in 2006-2011. Efficiency was measured by using stochastic frontier analysis. Variables used in the research consisted of loans from customers, commission income, securities (total loan, direct and indirect funding), deposits, labor price (ratio of salary expenses on the number of labors), capital cost (ration of other expenses on capital), and deposit cost (ratio interest expense on customers). Their research findings conveyed that $\mathrm{BBC}$ had performed better than other banks by 80 percent, exceeding the average percentage that was 72 percent.

Hardianto \& Wulandari (2016) compared the efficiency of conventional banks vs Islamic banks in Indonesia for the 2011-2013 period. They used stochastic frontier approach and found the differences in the level of efficiency between Islamic banks and conventional banks. Islamic banks have worse efficiency levels compared to conventional banks.

Sadono (2017) observed technical efficiency on Islamic rural banks in East Java in 2011-2016 by implementing stochastic frontier analysis and unbalanced panel data. Sadono used the bank approach as an intermediary to determine input. Input consisted of total deposits (saving deposits, mudharabahsavings, and mudharabahdeposits) and total operating cost; while output consisted of total earning assets (placement with Bank Indonesia, placement with other banks, murabahahfinancing, istishna' financing, mudharabahfinancing, musyarakahfinancing, ijarah, qardh, and multijasa). The research findings conveyed that Islamic rural banks in East Java in 2011-2016 realized technical efficiency by 90.12 percent in overall.

Jatmiko (2017) examined the effect of ownership structure on technical efficiency of both Islamic and conventional rural banks in Indonesia. His study estimated the efficiency score of Islamic and conventional rural banks using stochastic frontier analysis. The findings suggested that the gap of efficiency level holds among the Islamic rural banks, yet unobservable in the case of their conventional counterparts. Stochastic frontier analysis documented that inefficiency does matter in the case of Islamic rural banks only, while it seems not the case for conventional rural banks. Moreover, the inefficiency of Islamic rural banks is getting worse over time. 
Agustina, Sholihin, \& Fithria|The Efficiency of Indonesian Islamic Rural Banks: A Stochastic Frontier Analysis.

\section{Methodology}

\section{Data}

Table 1. Sample

\begin{tabular}{lcc}
\hline Criteria & Sample & Observation \\
\hline IRB admitted in Financial Service Authority 2018 & 168 & 4,032 \\
IRB without complete quartile financial reports & & $(110)$ \\
$\begin{array}{l}\text { during 2011 I Quartile I 2011-Quartile IV 2016 } \\
\text { Sample used in testing }\end{array}$ & 58 & $1.640)$ \\
\hline \multicolumn{2}{r}{ Source: author } &
\end{tabular}

This research uses financial report data of Islamic Rural Banks (IRB) in Indonesia in 2011-2016. Research sample is presented in Table 1.

The number of Islamic rural banks presented in Table 1 as research sample is 58 Islamic rural banks, out of the total 168 Islamic rural banks in Indonesia. The sample is determined by applying the purposive sampling method. Islamic rural banks criteria as sample included Islamic rural banks reporting complete quartile financial reports during Quartile I 2011- Quartile IV 2016.

This research is quantitative research. Data used in this research are balanced panel data gathered from financial reports of Islamic rural banks in Indonesia in Quartile I 2011-Quartile IV 2016 available and accessible on the Financial Service Authority (OJK) website. Although several financial report data had not been audited, we had compared the financial report before being audited and financial report data after being audited for some Islamic rural banks. Comparison results defined audited report was not different from non-audited report.

\section{Method}

Efficiency is measured by using the parametric method applying stochastic frontier analysis (SFA), because SFA approach has a specific, functional form for the production relationship between input and output, making the derived result more accurate. Additionally, SFA approach permits random errors.

Technical efficiency refers to the ability of producing optimum output by certain inputs (output-oriented) or the ability of using minimum input to gain a certain output (input-oriented) (Tahir,et al., 2008). This research 
Agustina, Sholihin, \& Fithria|The Efficiency of Indonesian Islamic Rural Banks: A Stochastic Frontier Analysis.

implements the output-oriented measurement that measures efficiency value upon costs incurred by banks while they altered input to be output. Efficiency value is compared to the best practice that generating similar output with a similar condition as well. This research uses the SFA approach proposed byBattese \& Coelli (1992)by applying this following equation:

$$
Y_{i t}=f\left(X_{i t} ; \beta\right)+\left(V_{i t}-U_{i t}\right) \quad i=1,2, \ldots, N ; t=1,2, \ldots, T
$$

$Y_{i t}$ is the variable indicating output for bank $\mathrm{k}_{\mathrm{i}}$ during $\mathrm{t}, X_{i t}$ is the vector whose value was input function for bank $k_{i}$ during $t, \beta$ is the unidentified parameter vector, $V_{i t}$ is assumed as independent and identically, distribution of random error has a normal distribution and is independent on $U_{i t}, U_{i t}$ is the unobservable non-negative random variable related to technical ineffienciency of production. Technical inefficiency of bank $k_{i}$ during $t$ can be defined by implementing the stochastic frontier model:

$$
T E=\exp \left(-U_{i t}\right)
$$

$U_{i t}$ is the variable indicated the model inefficiency. Initial step to estimate efficiency is by determining functional form for production function. The research implements the form of Cobb Douglas production function model and the input consists of capital and labor with fix technological assumption. Determining input and output size of a bank is important. Accurate input and output size are important in bank production model. There are two common approaches applied to determine bank input and output measurement, i.e. production approach and intermediaries approach. Referring to the production approach, each bank activity producing true resources is categorized as bank output(De, 2004). Benston, Hanweck, \& Humphrey (1982) believed that output had to be measured when bank was doing activities resulting in incurred cost. In terms of production approach, output should have been measured based on the number and types of transaction or account; while input could be measured by only using physical units as labors and capital(Hasan, et al., 2012).

Intermediaries approach defined output as financial intermediary between obligation holders and parties receiving fund from banks (De, 2004). According to research performed by Sealey \& Lindley (1977), loans and other assets were bank outputs, since able to give direct profits to the banks; while deposits and other obligations were inputs for intermediation process as the main material of investment fund. This research implemented the intermediaries approach. In it, banks as a financial intermediary combined deposits, labor, and capital to produce loans and investments(Tahir,et al., 2008). 
Agustina, Sholihin, \& Fithria|The Efficiency of Indonesian Islamic Rural Banks: A Stochastic Frontier Analysis.

The Stochastic Frontier model in this research is the modified Cobb Douglas model:

$$
\ln \left(T E A_{i t}\right)=\beta_{0}+\beta_{1} \operatorname{lnT} D_{i t}+\beta_{2} \ln T O E_{i t}+V_{i t}-U_{i t}
$$

\section{Description:}

1. $T E A_{i t}$, total earning assets (total productive active), is the total sum of Islamic bank fund investments in either Rupiah or foreign currencies in forms of mudharabahfinancing, musyarakahfinancing, murabahahloan, salamloan, istishna' loan, multi-service loan, ijarah, qardh, and placement with other banks.

2. $T D_{i t}$, total deposits, is the total sum of deposits from wadiahsaving account, mudharabahsaving, and mudharabahdeposit.

3. $T O E_{i t}$, total operating expenses, is the total sum of operational expenses from personal load account and other operational expenses.

4. $V_{i t}$, statistical noise, is random error from factors unexplainable by data.

5. $U_{i t}$, technical inefficiency described by the size variable.

This research measures efficiency value by applying the frontier approach, SFA. Technical efficiency is measured by implementing the Cobb Douglas model. Variables used are total earnings assets, total deposits, and total operating expense. SFA measurement is conducted by using the Maximumlikelihood Estimates (MLE) calculation to measure the SFA model parameter by using the STATA software. When the efficiency value is one, then bank has completely, efficiently operated. On the contrary, when the efficiency value is closer to zero, then bank operates more inefficiently.

\section{Results and Analysis}

\section{Descriptive Statistics}

Table 2 shows descriptive statistics of the value of variables used in the research that are total earnings assets, total deposits, and total operating expenses. The number of observations used is 1,392 for each variable.

Total earning assets has the mean of IDR30,001,140,000; minimum value of IDR942,053,000; maximum value of IDR503,819,900,000 with standard deviation of IDR51,736,460.000; Total deposits has the mean of 
Agustina, Sholihin, \& Fithria|The Efficiency of Indonesian Islamic Rural Banks: A Stochastic Frontier Analysis.

Table 2. Descriptive Statistics(in billion Rupiahs)

\begin{tabular}{cccccc}
\hline Variable & Observation & Mean & Standard Deviation & Minimum & Maximum \\
\hline TEA & 1392 & 30.00114 & 51.73646 & 0.942053 & 503.8199 \\
TD & 1392 & 21.49659 & 42.91089 & 0.427875 & 429.6731 \\
TOE & 1392 & 1.131709 & 1.610528 & 0.046766 & 19.11921 \\
\hline
\end{tabular}

Description: TEA is total earnings assets, TD is total deposits, TOE is total operating expenses

IDR21,496,590,000; minimum value of IDR427,875,000; maximum value of IDR429,673,100 with standard deviation of IDR42,910,890. Total operating expenses has the mean of IDR1,131,709,000; minimum value of IDR46,766,000; maximum value of IDR19,119,210,000 with standard deviation of IDR1,610,528,000.

\section{Results}

This research measures efficiency by using the parametric method by stochastic frontier analysis. Table 3 presents estimated results of Stochastic Frontier Analysis.

Based on frontier estimated results in Table 3, the total deposit variable and the total operating expense variable give a positive and significant effect on the total earnings asset variable. It implies that when total deposits increase by 1 percent, then total earnings assets will increase by 0.652 percent with assumption ceteris paribus. Moreover, when total operating expenses increase by 1 percent, then total earnings assets will also increase by 0.183 percent with assumption ceteris paribus.

Table 3. Estimated Result of Stochastic Frontier Analysis

\begin{tabular}{cc}
\hline Variable & InTEA \\
\hline \multirow{2}{*}{ Constanta } & $1.519^{* * *}$ \\
& $(0.038)$ \\
InTD & $0.652^{* * *}$ \\
& $(0.011)$ \\
InTOE & $0.183^{* * *}$ \\
& $(0.111)$ \\
\hline
\end{tabular}

Description: Bracketed numbers indicated the standard error, ${ }^{*}$ indicates significance at $\alpha=10$ percent, ** indicates significance at $\alpha=5$ percent, and ${ }^{* * *}$ indicates significance at $\alpha=1$ percent. 
Agustina, Sholihin, \& Fithria|The Efficiency of Indonesian Islamic Rural Banks: A Stochastic Frontier Analysis.

\section{Analysis}

Mean of Quartile I 2011-Quartile IV 2016Technical Efficiency

Table 4. Mean of Technical Efficiency

\begin{tabular}{cccccc}
\hline Variable & Observation & Mean & $\begin{array}{c}\text { Standard } \\
\text { Deviation }\end{array}$ & Minimum & Maximum \\
\hline $\begin{array}{l}\text { Technical } \\
\text { Efficiency }\end{array}$ & 1,392 & 0.8616744 & 0.1046564 & 0.4313468 & 0.9931033 \\
\hline
\end{tabular}

Table 4 presents the mean of Islamic rural bank efficiency by using the data of Quartile I 2011-quartal IV 2016efficiency values.

Seen in Table 1, the mean of Islamic rural bank technical efficiency in 20112016 is 86 percent. Islamic rural bank might achieve a perfect operational efficiency level by enhancing technical efficiency by 14 percent.

Technical Efficiency of Each Bank

Table 5 indicates that the mean technical efficiency score of each Islamic rural bank is derived by using data of quartile I 2011- quartile IV 2016efficiency with the total bank sample of 58.

Table 5. Mean of Technical Efficiency for Each Bank

No.

Bank
Mean of Technical Efficiency (Q1 2011-Q4 2016)
Ranking

$\begin{array}{ll}0.9903076 & 1 \\ 0.9775620 & 2 \\ 0.9745926 & 3 \\ 0.9716299 & 4 \\ 0.9708430 & 5 \\ 0.9618235 & 6 \\ 0.9571605 & 7 \\ 0.9551929 & 8 \\ 0.9446097 & 9 \\ 0.9437721 & 10 \\ 0.9436749 & 11 \\ 0.9429855 & 12 \\ 0.9354644 & 13 \\ 0.9291878 & 14 \\ 0.9282244 & 15 \\ 0.9271457 & 16 \\ 0.9268467 & 17 \\ 0.9203029 & 18\end{array}$


Agustina, Sholihin, \& Fithria|The Efficiency of Indonesian Islamic Rural Banks: A Stochastic Frontier Analysis.

\begin{tabular}{|c|c|c|c|}
\hline No. & Bank & $\begin{array}{c}\text { Mean of Technical Efficiency } \\
\text { (Q1 2011-Q4 2016) }\end{array}$ & Ranking \\
\hline 19 & PT BPRS Tanggamus & 0.9181809 & 19 \\
\hline 20 & PT BPRS GunungSlamet & 0.9152225 & 20 \\
\hline 21 & PT BPRS HikmahWakilah & 0.9137967 & 21 \\
\hline 22 & PT BPRS PatuhBeramal & 0.9132491 & 22 \\
\hline 23 & PT BPRS KaryaMugiSentosa & 0.9119772 & 23 \\
\hline 24 & PT BPRS BerkahRamadhan & 0.9050992 & 24 \\
\hline 25 & PT BPRS BumiRinjaniBatu & 0.9049591 & 25 \\
\hline 26 & PT BPRS ArtaLeksana & 0.9044609 & 26 \\
\hline 27 & PT BPRS Dana Hidayatullah & 0.9023322 & 27 \\
\hline 28 & PT BPRS Situbondo & 0.8971646 & 28 \\
\hline 29 & PT BPRS Sarana Prima Mandiri & 0.8923969 & 29 \\
\hline 30 & PT BPRS Indo Timur & 0.8858325 & 30 \\
\hline 31 & PT BPRS MuamalahCilegon & 0.8840127 & 31 \\
\hline 32 & PT BPRS BumiArthaSampang & 0.8783557 & 32 \\
\hline 33 & PT BPRS Artha Mas Abadi & 0.8662432 & 33 \\
\hline 34 & PT BPRS Cempaka AI Amin & 0.8625025 & 34 \\
\hline 35 & PT BPRS CaranaKiatAndalas & 0.8601880 & 35 \\
\hline 36 & PT BPRS Dana Mulia & 0.8564126 & 36 \\
\hline 37 & PT BPRS AI Washliyah & 0.8531617 & 37 \\
\hline 38 & PT BPRS Hareukat & 0.8487097 & 38 \\
\hline 39 & PT BPRS InsanCitaArtha Jaya & 0.8475308 & 39 \\
\hline 40 & PT BPRS DayaArthaMentari & 0.8438110 & 40 \\
\hline 41 & PT BPRS MitraHarmoni Kota Semarang & 0.8424659 & 41 \\
\hline 42 & PT BPRS Al HijrahAmanah & 0.8388393 & 42 \\
\hline 43 & PT BPRS KhasanahUmmat & 0.8386914 & 43 \\
\hline 44 & PT BPRS AmanahInsanCita & 0.7989681 & 44 \\
\hline 45 & PT BPRS Ummu & 0.7920750 & 45 \\
\hline 46 & PT BPRS IkhsanulAmal & 0.7892894 & 46 \\
\hline 47 & PT BPRS Hasanah & 0.7871073 & 47 \\
\hline 48 & PT BPRS Dana Amanah & 0.7801200 & 48 \\
\hline 49 & PT BPRS BinaAmwalulHasanah & 0.7716451 & 49 \\
\hline 50 & PT BPRS Kota Juang & 0.7591875 & 50 \\
\hline 51 & PT BPRS AI-Yaqin & 0.7549073 & 51 \\
\hline 52 & PT BPRS SyariatFajar Sejahtera Bali & 0.7425735 & 52 \\
\hline 53 & PT BPRS MeruSankara & 0.7286158 & 53 \\
\hline 54 & PT BPRS Madinah & 0.7182041 & 54 \\
\hline 55 & PT BPRS Surya Sejati & 0.6568281 & 55 \\
\hline 56 & PT BPRS UnawiBarokah & 0.6307738 & 56 \\
\hline 57 & PT BPRS Al Ihsan & 0.6270243 & 57 \\
\hline 58 & PT BPRS Bhakti Haji & 0.5725660 & 58 \\
\hline
\end{tabular}


Agustina, Sholihin, \& Fithria|The Efficiency of Indonesian Islamic Rural Banks: A Stochastic Frontier Analysis.

Based on Table 5, the most efficiently operating Islamic rural bank is PT BPRS HartalnsanKarimah with the mean technical efficiency score of 0.9903076; while the Islamic rural bank with the lowest mean technical efficiency score is PT BPRS Bhakti Haji with the mean technical efficiency score by 0.5725660 . In general, technical efficiency of Islamic rural banks in Indonesia in 20112016 is 86 percent, suggesting that there is still technical inefficiency of 14 percent that can be optimized.

IRB Efficiency Based on the Size Category

Table 6. Mean of IRB Efficiency Based on the Size Category

\begin{tabular}{llll}
\hline Category I & Category II & Category III & Category IV \\
\hline 0.724911012 & 0.852968906 & 0.909206199 & 0.959979383 \\
\hline
\end{tabular}

Table 6 is IRB efficiency table based on the bank size category. Bank size can be observed from the total IRB assets categorized into four. Category I is 25 percent of the lowest total assets; while Category IV is 25 percent of the highest total assets. Such categorization is to analyze the difference between big bank efficiency (Category IV) and small size bank (Category I).

Based on Table 6, Category I and Category IV have different mean of IRB efficiency that is by 23 percent, explaining that big IRBis more efficient than small IRB.

\section{Annual Efficiency of Islamic Rural Banks}

Table 7 indicates the mean of annual efficiency of Islamic rural banks. Based on the analysis results, the trend of annual IRB efficiency increases.

Table 7. Mean of Annual IRB Efficiency

\begin{tabular}{cc}
\hline Year & Efficiency \\
\hline 2011 & 0.826318345 \\
2012 & 0.849861588 \\
2013 & 0.865558973 \\
2014 & 0.871349735 \\
2015 & 0.876179081 \\
2016 & 0.880778553 \\
\hline
\end{tabular}




\section{Conclusion and Recommendation}

\section{Conclusion}

This research aims to investigate the efficiency level of Islamic rural banks (IRB) in Indonesia in 2011-2016. To achieve the aim, this research focuses on the analysis of Islamic rural bank efficiency using the stochastic frontier analysis (SFA) approach. Based on the SFA estimated result, the technical efficiency of Indonesian Islamic rural banks in 2011-2016 is 86 percent, so there is 14 percent of technical inefficient that can be optimized.

Top three Islamic rural banks in Indonesia are PT BPRS HartalnsanKarimah, PT BPRS AmanahUmmah, PT BPRS Dinar Ashri with the mean technical efficiency scores of 0.9903076, 0.9775620, and 0.9745926 respectively. Meanwhile, bottom three Islamic rural banks in Indonesiaare PT BPRS UnawiBarokah, PT BPRS Al Ihsan, and PT BPRS Bhakti Haji with the mean technical score are $0.6307738,0.6270243$, and 0.5725660 .

\section{Recommendation}

The research results are expected to be one of the considerations in decision-making for policy holders to assess efficiency.This research has several limitations in terms of data access. There are some IRB financial reports remaining unpublished on the Financial Service Authority website particularly in 2017, restricting this research to include data collected in 2017. Future research can be focused on factors causing the inefficiency of Islamic rural banks. 
Agustina, Sholihin, \& Fithria|The Efficiency of Indonesian Islamic Rural Banks: A Stochastic Frontier Analysis.

\section{References}

Aiello, F., \& Bonanno, G. (2016). Bank efficiency and local market conditions: Evidence from Italy. Journal of Economics and Business, 83, 70-90. https://doi.org/10.1016/j.jeconbus.2015.09.002

Aigner, D., Lovell, C.A.K., \& Schmidt, P. (1977). Formulation and Estimation of Stochastic Frontier Production Function Models. Journal of Econometrics, 6, 21-37. https://doi.org/10.1016/03044076(77)90052-5

Aysan, A.F., Karakaya, M.M., \& Uyanik, M. (2011). Panel Stochastic Frontier Analysis of Profitability and Efficiency of Turkish Banking Sector in the Post Crisis Era. Journal of Business Economics and Management, 12(4), 629-654. https://doi.org/10.3846/16111699.2011.599411

Battese, G.E., \& Coelli, T.J. (1992). Frontier Production Functions, Technical Efficiency and Panel Data: With Application to Paddy Farmers in India. Journal of Productivity Analysis, 3, 153-169.

Benston, G.J., Hanweck, G. A., \& Humphrey, D.B. (1982). Scale Economies in Banking: A Restructuring and Reassessment. Journal of Money, Credit and Banking, 14(4), 435-456.

Berger, A.N., \& Humphrey, D.B. (1997). Efficiency of Financial Institutions: International Survey and Directions for Future Research.

Bhattacharyya, A.,\& Pal, S. (2013). Financial reforms and technical efficiency in Indian commercial banking: A generalized stochastic frontier analysis. Review of Financial Economics, 22(3), 109-117. https://doi.org/10.1016/j.rfe.2013.04.002

Bokpin, G.A. (2013). Ownership structure, corporate governance and bank efficiency: an empirical analysis of panel data from the banking industry in Ghana. Corporate Governance: The International Journal of Business in Society, 13(3), 274-287. https://doi.org/10.1108/CG05-2010-0041

De, P.K. (2004). Technical Efficiency, Ownership, And Reforms: An Econometric Study of Indian Banking Industry. Indian Economic Review, 39(1), 261-294.

Farrel, M. J. (1957). The Measurement of Productive Efficiency. Journal of the Royal Statistical Society, 120(3), 253-290.

Fase, M.M.G., \& Abma, R.C.N. (2003). Financial environment and economic growth in selected Asian countries. Journal of Asian Economics, 14(1), 11-21. https://doi.org/10.1016/S1049-0078(02)00237-3

Hadad, M.D., Santoso, W., Mardanugraha, E., \& Illyas, D. (2003). Pendekatan Parametrik Untuk Efisiensi Perbankan Indonesia. Jurnal Bank Indonesia.

Hardianto, D.S., \& Wulandari, P. (2016). Islamic Bank vs Conventional Bank: Intermediation, Fee Based Service Activity and Efficiency. International Journal of Islamic and Middle Eastern Finance and Management, 9(2), 296-311. https://doi.org/10.1108/IMEFM-012015-0003

Hasan, M.Z., Kamil, A.A., Mustafa, A., \& Baten, M.A. (2012). A Cobb Douglas Stochastic Frontier Model on Measuring Domestic Bank Efficiency in Malaysia. PLOS ONE, 7(8), 1-5. 
Agustina, Sholihin, \& Fithria $\mid$ The Efficiency of Indonesian Islamic Rural Banks: A Stochastic Frontier Analysis.

https://doi.org/10.1371/journal.pone.0042215

Holod, D., \& Lewis, H.F. (2011). Resolving the deposit dilemma: A new DEA bank efficiency model. Journal of Banking and Finance, 35(11), 28012810. https://doi.org/10.1016/j.jbankfin.2011.03.007

Hosen, M.N., \& Muhari, S. (2013). Efficiency of the Sharia Rural Bank in Indonesia Lead to Modified Camel. International Journal of Academic Research in Economics and Management Sciences, 2(5), 34-53. https://doi.org/10.6007/IJAREMS/v2-i5/298

Jatmiko, W. (2017). Efficiency and Ownership Structure: Evidence from Rural Banks in Indonesia. International Journal of Economics, Management and Accounting, 25(2), 355-380.

Khalib, M., Abdul-Rahman, A., \& Janor, H. (2016). Impak Kecekapan Kos terhadap Risiko Kecairan dalam Institusi Perbankan di Malaysia. Jurnal Pengurusan, 47. https://doi.org/10.17576/pengurusan-201647-06

Kumbhakar, S.C., \& Lovell, C.A.K. (2000). Análise de experimentos em látice quadrado com ênfase em componentes de variância.: II. Análise conjunta. Cambridge University Press. https://doi.org/10.1177/1077558707307580

Manlagnit, M.C.V. (2015). Basel regulations and banks' efficiency: The case of the Philippines. Journal of Asian Economics, 39, 72-85. https://doi.org/10.1016/j.asieco.2015.06.001

Meeusen, W., \& Broeck, J. van Den. (1977). Efficiency Estimation from CobbDouglas Production Functions with Composed Error. International Economic Review, 18(2), 435-444.

Muazaroh. (2013). Pengukuran Efisiensi dan Faktor Penentu Tingkat Efisiensi Bank di Indonesia. Universitas Gadjah Mada.

OJK. (2016). Booklet Perbankan Indonesia 2016.

OJK. (2017). Laporan Perkembangan Keuangan Syariah 2016.

OJK. (2018). Statistik Perbankan Syariah - Juni 2018.

Parinduri, R.A., \& Riyanto, Y.E. (2014). Bank Ownership and Efficiency in the Aftermath of Financial Crises: Evidence from Indonesia. Review of Development Economics, 18(1), 93-106. https://doi.org/10.1111/rode.12071

Qurniawati, R.S. (2013). Efisiensi Perbankan di Indonesia dan Pengaruhnya Terhadap Return Saham dengan Pendekatan Data Envelopment Analysis (DEA). BENEFIT Jurnal Manajemen Dan Bisnis, 17(1), 27-40.

Rose, P.S., \& Hudgins, S.C. (2013). Bank Management \& Financial Services (9th Editio). Singapore: McGraw-Hill.

Sadono, E.D. (2017). Efficiency of Islamic Rural Banks (BPRS) in East Java Provice, Indonesia. Tazkia Islamic Finance and Business Review, 11(1-14).

Sealey, C.W., \& Lindley, J.T. (1977). Inputs, Outputs, and a Theory of Production and Cost at Depository Financial Institutions. The Journal of Finance, 32(4), 1251-1266.

Tahir, I.M., Bakar, N.M.A., \& Haron, S. (2008). Technical efficiency of the Malaysian commercial banks: A stochastic frontier approach. Banks and Bank Systems, 3(4), 65-72.

Undang-Undang Nomor 21 Tahun 2008 Tentang Perbankan Syariah. (n.d.).

Zhang, P., \& Kang, S. (2015). Cost Efficiency of Chinese Banks-Using 
Agustina, Sholihin, \& Fithria|The Efficiency of Indonesian Islamic Rural Banks: A Stochastic Frontier Analysis.

Stochastic Frontier Analysis. International Journal of Management and Applied Science, 1(10), 105-108.

Zuhroh, I., Ismail, M., \& Maskie, G. (2015). Cost Efficiency of Islamic Banks in Indonesia - A Stochastic Frontier Analysis. Procedia-Social and Behavioral Sciences, 211, 1122-1131.

https://doi.org/10.1016/j.sbspro.2015.11.150 
Agustina, Sholihin, \& Fithria|The Efficiency of Indonesian Islamic Rural Banks: A Stochastic Frontier Analysis.

This page is intentionally left blank

IJIEF: InternationalJournal of Islamic Economics and Finance, 1(2), 229-248| 248 